\title{
EKSPLORASI BAKTERI ENTOMOPATOGENIK PENGENDALI HAMA Plutella xylostella DAN Spodoptera Sp. PADA TANAMAN KUBIS BUNGA DAN BROKOLI
}

\author{
EXPLORATION OF ENTOMOPATHOGENIC BACTERIA FOR BIO-PESTICIDE TO \\ CONTROL Plutella xylostella AND Spodoptera sp. ON CABBAGE AND BROCCOLI
}

\author{
Christina L.Salaki*) \\ *Jurusan Hama dan Penyakit Tumbuhan, Fakultas Pertanian Unsrat Manado
}

\begin{abstract}
The research aimed to explore potential entomopathogenic bacteria as biological control agent for insect pest of $P$. xylostella and Spodoptera sp. in cabbage and broccoli. The indigenous bacteria were explored by taking 103 samples from location around North Sulawesi. Bacteria were selectively isolated by using Ohba and Aizawa method and then identified based on morphology. Subsequently the isolates were screened by their potency to kill test insect of $P$. xylostella and Spodoptera $s p$. The isolates were able to kill $\geq 50 \%$ test insect considered as potential for biological control. The potential isolates were then selected and would be developed as powder and liquid bio-pesticide through large scale production. The result of the study showed that 145 Bacillus thuringiensis isolates and 202 Bacillus cereus isolates were obtained from 103 samples. The screening of the isolates based on standard test insect for cabbage and broccoli were in progress. The potential isolates would be further selected on the basis of their pathogenicity test. Based on pathogenecity test, chosen isolates will be developed as biopasticide to control insect pest of cabbage and broccoli.
\end{abstract}

Keywords : Exploration, entomopathogenic bacteria, biological control, Plutella xylostella, Spodoptera Sp.

\begin{abstract}
ABSTRAK
Penelitian ini bertujuan untuk memperoleh isolat bakteri entomopatogenik yang berpotensi sebagai pengendali hayati terhadap hama $P$. xylostella dan Spodoptera sp., pada tanaman kubis dan brokoli. Bakteri endogenik dieksplorasi dengan mengambil sebanyak 103 sampel dari berbagai lokasi di daerah Sulawesi Utara. Bakteri diisolasi secara selektif dengan menggunakan metode Ohba dan Aizawa kemudian diidentifikasi berdasarkan morfologi. Selanjutnya, isolat bakteri diskriming berdasarkan daya bunuhnya terhadap serangga uji $P$. xylostella dan Spodoptera sp. isolat bakteri yang mampu membunuh serangga uji $\geq 50 \%$ dianggap isolat yang berpotensi. Isolat yang berpotensi selanjutnya di seleksi untuk memperoleh isolat unggul yang akan di kembangkan menjadi biopestisida dalam bentuk serbuk dan cairan melalui teknik produksi skala besar. Hasil penelitian menunjukan bahwa dari 103 sampel diperoleh 149 isolat yang diidentifikasi sebagai Bacillus thuringiensis dan 202 isolat yang diidentifikasi sebagai $B$. cereus. Skrining terhadap isolat berdasarkan serangga uji standar masih berlangsung sampai saat ini. Isolat yang berpotensi selanjutnya akan diseleksi berdasarkan patogeisitasnya untuk selanjutanya isolat unggul akan dikembangkan menjadi bio-pestisida untuk mengendalikan hama $P$. xylostella dan Spodoptera sp. pada tanaman kubis dan brokoli

Kata kunci : Eksplorasi, bakteri entomopatogenik, pengendali hayati, Plutella xylostella, Spodoptera sp.
\end{abstract}




\section{PENDAHULUAN}

Kubis bunga dan Brokoli sampai saat ini masih termasuk sayuran mewah, harganya cukup mahal, dan konsumennya sebagian besar adalah penduduk di kota-kota besar (Rukmana, 1996; Husaini, 2010; Wikipedia, 2011).

Pengembangan budidaya kubis bunga dan brokoli menjanjikan prospek yang cerah, menunjang perbaikan gizi masyarakat, meningkatkan pendapatan petani, mengurangi impor dan meningkatkan ekspor non migas, memperluas kesempatan kerja, mengembangkan agribisnis, melestarikan dan meningkatkan kualitas lingkungan. Meskipun demikian, fakta di lapangan menunjukkan bahwa pengembangan komoditas ini masih terbatas di daerah dataran tinggi, dan luas arealnya jauh di bawah kubis krop dan petsai. Brokoli memiliki beragam manfaat untuk kesehatan tubuh, seperti mencegah terjadinya kanker kolon, kanker prostat, kanker paru dan kanker perut. Zat sulfotraphana bermanfaat sebagai antioksidan, sedangkan seratnya bermanfaat untuk mencegah konstipasi/sembelit dan gangguan pencernaan lainnya (Husaini, 2010; Wikipedia, 2011).

Keengganan para petani atau pengusaha tani membudidayakan kubis bunga dan brokoli antara lain karena masih terbatasnya informasi mengenai aspek teknik, ekonomi, dan sosialnya komoditas ini. Semula banyak beranggapan bahwa kubis bunga dan brokoli hanya cocok di tanam di dataran tinggi dengan perawatan tanaman secara khusus.

Akhir-akhir ini permintaan kubis bunga maupun brokoli semakin meningkat, baik untuk konsumsi dalam negeri maupun eksport. Meningkatnya permintaan ini dapat dipenuhi dengan memperluas pertanamannya, sehingga makin meningkat pula kebutuhan benih.

Berbagai usaha telah dilakukan untuk memperluas pertanamannya dan meningkatkan produksinya. Usaha tersebut antara lain dengan intensifikasi dan ekstensifikasinya. Untuk meningkatkan kualitas dan kuantitas produksi diperlukan cara pemeliharaan yang baik. Dalam usaha meningkatkan produksi kubis bunga dan brokoli ini banyak faktor penghambat yang harus dihadapi, antara lain adalah gangguan hama (plutella xylostella dan spodoptera sp.) Salah satu faktor penting yang harus mendapat perhatian adalah pengendalian hama (Capinera, 2010; Rondonuwuet et. al., 2003).

Sampai saat ini titik berat pengendalian hama tanaman kubis bunga dan brokoli masih mengandalkan pengendalian kimia secara berlebihan baik dari segi dosis maupun jumlah perlakuan. Ditinjau dari segi penekanan populasi hama penguasaan inteksida berhasil baik, namun diingat adanya pengaruh samping yang tidak diinginkan (Oka, 1995; Sembel, 2010; Untung, 2006).

Pengaruh samping akibat penggunaan intektisida secara berlebihan adalah (a) kematian organism bukan sasaran (b) terjadinya resistensi dan resurgensi hama sasaran dan (c) residu insektisida pada bahan makanan. Untuk memperkecil timbulnya pengaruh samping dari penggunaan insektisida tersebut, alternatif lain dalam pengendalian perlu diusahakan (Oka, 1995; Untung, 2006; Sembel, 2010).

Adanya pengaruh buruk bagi lingkungan dan fenomena resistensi pada serangga hama akibat penggunaan insektisida telah meningkatkan perhatian para ahli terhadap penelitian tentang pemanfaatan patogen-patogen untuk mengendalikan hama-hama tanaman pertanian. Patogen serangga relatif bersifat spesifik dan pengaruhnya seandainya ada jauh lebih kecil dari pada yang ditimbulkan oleh bahan kimia terhadap lingkungan atau organisme bukan sasaran.

Mengingat hal-hal di atas maka pencarian strain-strain baru bakteri entomopatogenik yang endogenik perlu dilakukan di Indonesia sebagai upaya untuk meningkatkan pengendalian serangga hama secara hayati sebagai alternatif pengganti insektisida kimia. Pemanfaatan jasad renik ini sebagai agensia pengendali hayati merupakan suatu terobosan dalam peningkatkan pendayagunaan sumber daya hayati secara lebih intensif dan menyelamatkan lingkungan hidup dari pencemaran.

\section{METODE PENELITIAN}

\section{Pengambilan Contoh Tanah}

Pengambilan contoh tanah sebagai sumber isolat dilakukan pada tiga Kabupaten yaitu 
Kabupaten Minahasa Selatan, Minahasa, dan Kota Tomohon.

Contoh tanah dikoleksi dari areal pertanian, tanah hutan, kebun, rawa, sawah, tempattempat tertentu yang dicurigai mengandung endospora bakteri. Tanah diambil sebanyak 400 gram pada masing-masing tempat. Contoh tanah yang diambil dimasukkan ke dalam kantong plastik, diikat rapat, diberi label lokasi dan tanggal pengambilan kemudian di bawah ke laboratorium dan disimpan di dalam kulkas untuk diisolasi.

\section{Isolasi Bakteri Entomopatogenik}

Contoh tanah yang diambil di lapangan diisolasi dengan menggunakan metode Ohba and Aizawa (1978) dengan cara sebagai berikut: diambil 1 gram contoh tanah, dimasukkan ke dalam tabung reaksi yang telah berisi $9 \mathrm{ml}$ larutan ringer steril. Suspensi dikocok hingga homogen kemudian dipanasi dalam waterbath pada suhu $80^{\circ} \mathrm{C}$ selama 10 menit. Suspensi dibuat seri pengenceran dari $10^{-2}$ $10^{-4}$. Dari pengenceran $10^{-3}-10^{-4}$ diambil masingmasing $0,1 \mathrm{ml}$ diratakan di atas media NA, lalu petridis dibungkus dengan kertas sapul steril dan diletakkan dengan posisi terbalik. Inkubasi selama 48 jam pada suhu kamar $\left(28^{\circ}-30^{\circ} \mathrm{C}\right)$. Untuk seleksi awal, dari banyak koloni yang tumbuh dipilih karakteristik koloni dengan ciri-ciri morfologi : sel berbentuk batang, motil, gram positif, kolon circuler, warna koloni putih dan putih kekuningan. Dari koIoni ini dibuat sediaan preparat untuk diamati dengan mikroskop fase kontras pada pembesaran 1000 kali. Koloni bakteri yang menunjukkan ciri-ciri positif sebagai bakteri bacillus dibuat kultur murni untuk kemudian di masukkan ke dalam tabung berisi cairan yang mengandung $15 \%$ gliserol dan disimpan pada lemari es sebagai stok yang akan digunakan selama penelitian.

\section{Identifikasi}

Identifikasi dilakukan dengan mengamati morfologi sel dan koloni bakteri.

\section{Morfologi Sel Bakteri}

Untuk melihat morfologi sel maka biakan bakteri yang telah berumur 48-96 jam setelah inokulasi pada media biakan diamati di bawah mikros- kop fase kontras, untuk mengamati bentuk sel dan pertumbuhan spora serta Kristal protein.

\section{Morfologi Koloni Bakteri}

Untuk melihat koloni bakteri, maka bakteri ditumbuhkan pada media NA dan diamati setelah berumur 48-96 jam setelah inokulasi. Hal-hal yang diamati yaitu bentuk koloni, warna koloni, tepi koIoni, permukaan koloni, elefasi koloni.

\section{Uji Skrining Isolat $B$. cereus}

Sebagai tahap awal pendahuluan dilakukan pengujian isolat $B$. cereus terhadap larva $P$. xylostella, kemudian akan dilanjutkan dengan pengujian isolat-isolat lain yang telah ditemukan untuk diuji cobakan terhadap larva Spodoptera Sp.

Isolat $B$. cereus murni yang didapatkan dari berbagai contoh tanah diuji toksisitasnya terhadap larva $P$. xylostella. Tahap kegiatan yang akan dilakukan yaitu pembiakan massal serangga, penyiapan suspensi isolat dan pengujian toksisitas isolat terhadap larva uji.

\section{Pembiakan Massal Serangga}

Larva $P$. xylostella yang berasal dari lapang diambil dan dipelihara di laboratorium Entomologi Jurusan Hama dan Penyakit Tumbuhan dengan diberi makan daun kubis segar. Pada bagian bawah daun kubis disiapkan tanah untuk tempat membentuk pupa. Gumpalan tanah yang sudah terbentuk dan mengandung kepompong dipisahkan dan dimasukkan ke dalam kurungan kasa, yang di dalamnya digantungkan gumpalan kapas yang ditetesi madu untuk pakan imagonya. Kelompok telur pada permukaan daun hasil perbanyakan diletakkan dicawan petri yang berisi daun kubis, selanjutnya ditunggu hingga telur menetas dan larva berkembang menjadi instar III. Larva-larva tersebut diseleksi untuk mendapatkan larva yang umurnya homogen yang akan dipakai sebagai larva uji.

\section{Penyiapan Suspensi Isolat B. cereus}

Isolat $B$. cereus yang akan diuji toksisitasnya dibiakkan dalam media NA untuk perhitungan jumlah sporanya. Di samping itu seluruh koloni dalam satu tabung agar miring diencerkan 100 kali, untuk digunakan dalam pengujian pendahuluan. 
Pada uji pendahuluan perhitungan spora berdasarkan pada hasil perhitungan isolat lain yang digunakan atau dianggap sebagai standar. Penghitungan spora memakai haemositometer.

\section{Skrining Bakteri B. cereus}

Daun kubis yang akan digunakan untuk uji toksisitasnya dicuci sampai bersih dan dipotongpotong berbentuk lingkaran berdiameter $3 \mathrm{~cm}$. Potongan daun kubis diberi perlakuan $B$. cereus isolat lokal dari berbagai contoh tanah dari masingmasing pengenceran suspense dengan cara menyemprot daun-daun tersebut dengan alat penyemprot. Alat semprot yang akan digunakan, sebelum dan sesudahnya dicuci bersih untuk menghindari adanya kontaminasi dari pemakaian sebelumnya. Setiap permukaan atas daun kubis disemprot dengan volume suspens $2 \mathrm{ml}$, begitu pula pada permukaan bawah daun. Daun kubis yang akan digunakan sebagai kontrol disemprot dengan aquades steril dengan cara yang sama. Daun-daun yang sudah disemprot dimasukkan dalam cawan petri yang beralaskan kertas tissue dalam keadaan lembab.

Larva yang sudah dipuaskan sebelumnya dimasukkan dalam botol steril yang berisi daun kubis yang sudah diperlakukan, sebanyak 30 larva dimana masing-masing botol berisi 1 larva. Pengamatan mortalitas larva yang diuji dilakukan pada jam ke 24, 48, 72 dan 96 jam setelah perlakuan. Bila larva pada kontrol ada yang mati maka perhitungan mortalitas larva didasarkan pada rumus Abbot yaitu:

$$
P=\frac{P^{1}-C}{100-C} \times 100 \%
$$

Keterangan :

$\mathrm{P}=$ persentase mortalitas terkoreksi

$P^{1}=$ persentase mortalitas pengamatan

$\mathrm{C}=$ persentase mortalitas control

Penyesuaian yang dilakukan dengan formula Abbot ini, dilakukan untuk memperkirakan adanya kematian secara alami. Jika kematian kontrol mencapai $20 \%$ maka perlakuan diulang.

\section{HASIL DAN PEMBAHASAN}

\section{Eksplorasi Strain Bakteri Entomopatogen Isolasi Selektif Bakteri Entomopatogen}

Isolasi selektif bakteri entomopatogen ( $B$. thuringiensis, B. cereus, dan B.sphaericus) dari 103 sampel tanah berhasil memperoleh sebanyak 411 isolat bakteri bentuk batang pembentuk spora. seperti terlihat pada tabel 1. Terlihat Pada Tabel 1 bahwa jumlah isolat bakteri $B$. thuringiensis (145), B. cereus (202) dan B. sphaericus (64) berbeda untuk tiap kabupaten. Perbedaan ini disebabkan di daerah tertentu pencarian dilakukan lebih intensif dibandingkan dengan daerah lainnya. Dalam hubungannya dengan habitat tersebut, sebenarnya diperlukan pengambilan sampel berulang kali karena penemuan bakteri entomopatogenik pada suatu saat tertentu dipengaruhi oleh banyak faktor antara lain hujan dan erosi, epizootic dan endozootic, dan ada kemungkinan pada suatu saat ditemukan bakteri entomopatogenik di suatu tempat tertentu tetapi pada saat lain tidak dapat ditemukan lagi dan sebaliknya (Salaki dkk., 2010).

\section{Hasil Isolasi Bakteri}

Bacillus merupakan genus bakteri yang mampu membentuk struktur dorman yaitu endospora yang bersifat tahan terhadap bahan-bahan kimia dan perlakuan fisik seperti panas, UV dan kering. Perlakuan pemanasan $80^{\circ} \mathrm{C}$ Selama 10 menit pada metode isolasi ini, bertujuan agar mikrobia lain kecuali yang berbentuk endospora akan mati. Dengan demikian hanya bakteri-bakteri thermo-tolerant pembentuk spora yang tumbuh, dan dari jenis-jenis bakteri tersebut hanya bakteri aerobik saja yang dapat tumbuh karena kultur diinkubasi secara aerobik.

Hasil isolasi dari 103 sampel tanah dari 3 Kabupaten, didapatkan 411 isolat bakteri pembentuk spora. Pengamatan dengan mikroskop fase kontras, isolat-isolat tersebut menunjukkan ciri bakteri yang dikenal sebagai agensia hayati. Isolatisolat tersebut 145 isolat merupakan $B$. thuringiensis, 202 isolat sebagai $B$. cereus, dan 64 isolat yang menunjukkan ciri-ciri sebagai $B$. sphaericus. 
Tabel 1. Jumlah Sampel Tanah Dan Isolat Bakteri Entomopatogen Di Provinsi Sulawesi Utara (Table 1. Number of Soil Sample and Entomopathogenic Bacteria Isolate at Province North Sulawesi)

\begin{tabular}{lcccc}
\hline \multicolumn{1}{c}{ Kabupaten } & $\begin{array}{c}\text { Jumlah Sampel } \\
\text { Tanah }\end{array}$ & $\begin{array}{c}\text { Jumlah Isolat } \\
\text { B. thuringiensis }\end{array}$ & $\begin{array}{c}\text { Jumlah Isolat } \\
\text { B. cereus }\end{array}$ & $\begin{array}{c}\text { Jumlah Isolat } \\
\text { B. sphaericus }\end{array}$ \\
\hline 1. Minahasa Selatan & 17 & 4 & 37 & 8 \\
2. Minahasa & 70 & 114 & 111 & 47 \\
3. Kota Tomohon & 16 & 27 & 54 & 9 \\
\hline \multicolumn{1}{c}{ Total } & 103 & 145 & 202 & 64 \\
\hline
\end{tabular}

Isolat $B$. thuringiensis dicirikan oleh sel-sel vegetatifnya yang membentuk rantai spora berbentuk oval terletak sub terminal dan adanya kristal parasporal. Pada isolat-isolat bakteri ini kristal parasporal berbentuk bipiramidal dan spherical. Ciri spesifik B. sphaericus terlihat dari bentuk spora yang sferis dan mengembung, terletak subterminal hingga terminal (Heimpel, 1967) sehingga bentuk sel vegetatif menjadi seperti gada. $B$. cereus mempunyai sel vegetatif yang berbentuk batang dengan spora berbentuk ellips terletak pada bagian sentral atau parasentral, gram positif (Gambar 1, 2, dan 3).

\section{Karakterisitik dan Identifikasi \\ B. thuringiensis}

Hasil pengamatan secara makroskopi terhadap koloni-koloni yang diamati morfologinya ternyata menunjukkan karakteristik sebagai anggota spesies $B$. thuringiensis yaitu bentuk circular, permukaan koloni kasar dan licin, mengkilap dan agak mengkilap, warna koloni putih dan putih kekuningan.

Sel vegetatif bakteri $B$. thuringiensis berbentuk batang dengan spora subterminal. Bersamaan dengan terbentuknya spora dibentuk pula benda berupa kristal yang berada dekat spora yang dikenal dengan nama Kristal protein (Agaisse and Lereclus, 1995; Bravo, 1997; Ggroschulski et.al., 1995; Salaki, 2010). Pada umur biakan satu hari spora dan Kristal belum terbentuk, namun baru terlihat pada umurdua hari setelah diinokluasi. Adanya Kristal protein di dekat spora menunjukkan bahwa sebanyak 145 isolat diidentifikasi sebagai anggota B. thuringiensis.

\section{Bacillus sphaericus}

Warna koloni putih kekuningan dan permukaan licin, bentuk batang (seperti gada) soliter, spora sferis dan membengkak, gram positif. (Alexander and Priest, 1990; Krych et.al., 1980)

\section{Bacillus cereus}

Berdasarkan hasil pengamatan pertumbuhan bakteri $B$. cereus pada media NA terlihat bahwa koloni berbentuk irregular, permukaan koloni kasar, datar dan agak mengkilap. Warna koloni putih kekuningan. Hal ini sesuai dengan yang dikemukakan oleh Parry et.al., (1983) bahwa koloni yang tumbuh pada media agar darah menunjukkan pertumbuhan yang bundar hingga irregular dan fimbriat dengan elevasi rendah hingga cembung.

$B$. cereus dapat tumbuh dengan baik pada media NA yang diinkubasi di laboratorium yag mempunyai suhu rata-rata $28,8^{\circ} \mathrm{C}$. Menurut Gordon et.al., (1973) B. cereus dapat tumbuh dengan baik pada suhu maksimum $35^{\circ} \mathrm{C}$ sampai $45^{\circ} \mathrm{C}$ dan suhu minimum $10^{\circ} \mathrm{C}$ sampai $20^{\circ} \mathrm{C}$. Permukaan koloni yang tumbuh pada NA tampak mengkilap dan dapat memantulkan cahaya. Bakteri yang berumur 8 hari dapat menimbulkan bau busuk (Granum et.al., 1993; Binoto, 2001).

Pada pengamatan secara mikroskopis ternyata $B$. cereus yang berumur sampai 24 jam setelah inokulasi belum membentuk spora. Spora baru terlihat setelah pengamatan 48 setelah inokulasi. Spora tampak lisis pada pengamatan 96 jam setelah inokulasi. Hal ini ditunjang oleh pendapat yang dikemukakan oleh Gordon et al., (1973); Lechener et al., (1998) bahwa spora B. cereus mengalami perkembangan yang nyata pada umur 48 sampai 168 jam setelah inokulasi. Kimball (1965) mengatakan bakteri berkebang biak (multiplikasi) dengan cara membelah diri dari satu sel menjadi dua sel pada kondisi yang sesuai untuk pertumbuhannya. Spora $B$. cereus terdapat pada bagian para sentral, berbentuk elips dan berwarna putih. 

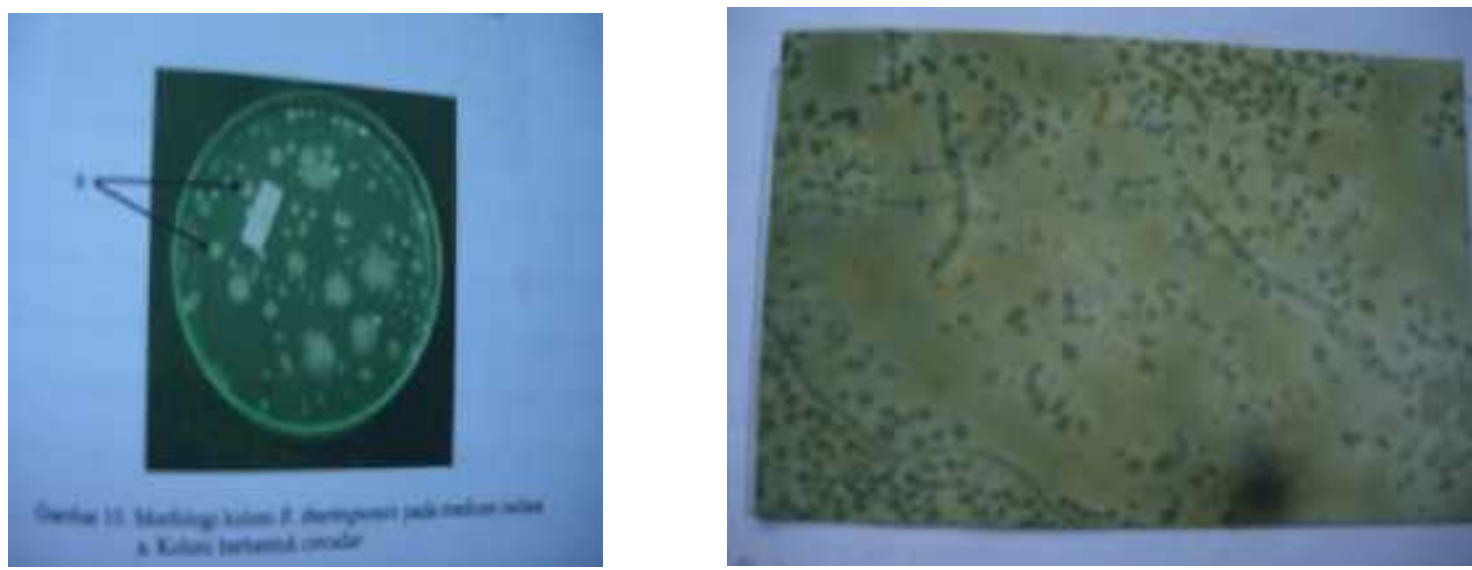

Gambar 1. Morfologi koloni dan sel-sel vegetatif Bacillus thuringiensis

(Figure 1. Colonial Morphology and Vegetative Cell Bacillus thuringiensis)
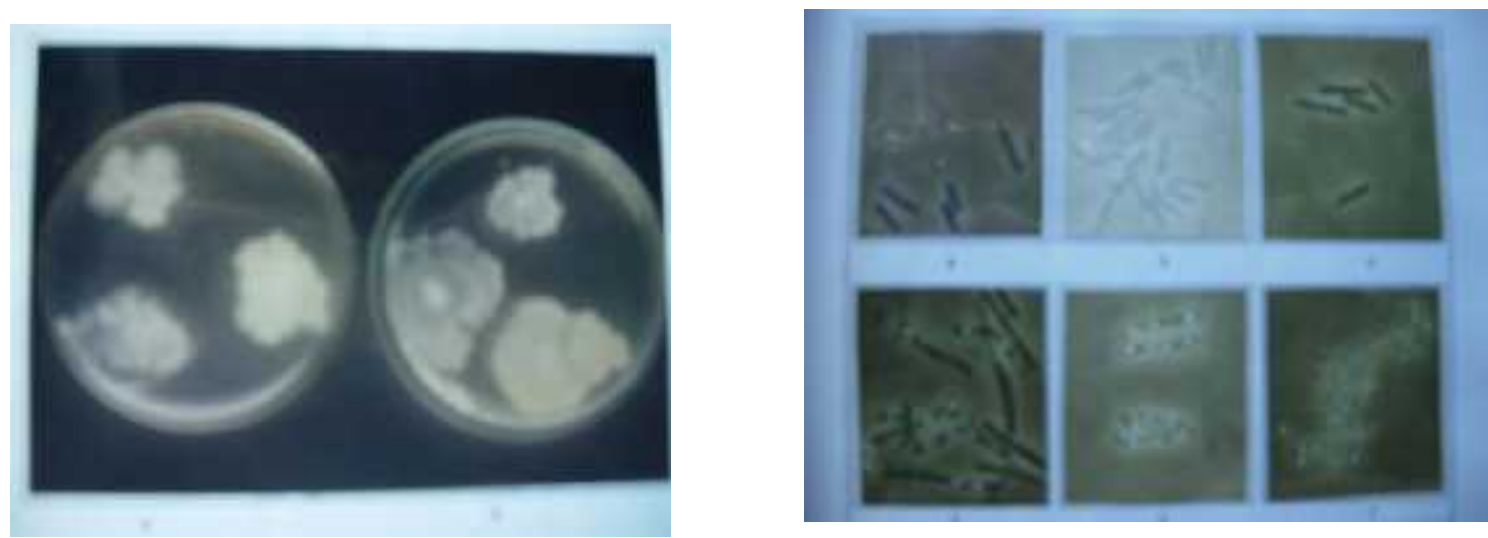

Gambar 2. Morfologi koloni dan sel-sel vegetatif Bacillus cereus

(Figure 2. Colonial Morphology and Vegetative Cell Bacillus cereus)

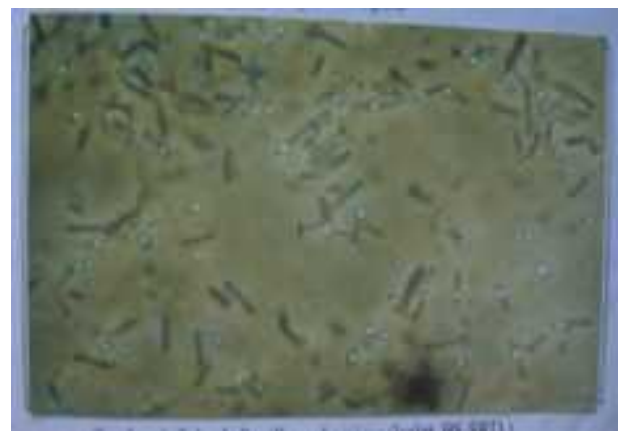

Gambar 3. Sel Vegetatif Bacillus sphaericus

(Figure 3. Vegetative Cell of Bacillus sphaericus)

B. Screening Isolat B. cereus Berdasarkan Uji Daya Bunuh Terhadap Larva P. xylostella

Uji daya bunuh dilakukan terhadap sebagi-

an isolat $B$. cereus yang dipilih mewakili tiap kabupaten. Dari hasil pengamatan morfologi koloni dan sel vegetatif dipilih 15 isolat yang diuji pada taraf pendahuluan terhadap larva $P$. xylostella. Hasil pengujian disajikan pada Tabel 2. 
Tabel 2. Hasil Pengujian Screening Daya Bunuh Isolat Bakteri B. cereus Terhadap Larva P. xylostella Selama Pendedahan 96 jam

(Table 2. Screening of B. cereus for ability to kill P. xylostella larvae (96 hours)

\begin{tabular}{cccc}
\hline No. & Kode Isolat & Kabupaten & Mortalitas (\%) \\
\hline 1 & PPT & Minahasa Selatan & 36,7 \\
2. & RNP $^{*}$ & Minahasa Selatan & 86,7 \\
3. & MTC $^{*}$ & Minahasa Selatan & 56,7 \\
4 & TEK & Minahasa Selatan & 30,0 \\
5. & LBH $^{*}$ & Minahasa Selatan & 83,3 \\
6. & NOH $^{*}$ & Minahasa & 70,0 \\
7 & ATP1 $^{*}$ & Minahasa & 63,3 \\
8. & SDR2 $_{9}$ & Minahasa & 40,0 \\
9. & RWK1 $^{*}$ & Minahasa & 93,3 \\
10. & SDK1 $_{1 .}$ & Minahasa & 40,0 \\
1. & PPT $^{*}$ & Minahasa & 86,7 \\
12. & TOR $^{*}$ & Minahasa & 90,0 \\
13. & RRK $_{1 .}$ & Tomohon & 33,3 \\
14. & RRO $^{*}$ & Tomohon & 76,7 \\
15. & RRW $^{*}$ & Tomohon & 100, \\
\hline
\end{tabular}

Dari hasil pengujian semua bakteri tersebut terdapat 10 isolat yang dapat mematikan larva P.xylostella 7,50 \% setelah 96 jam pada konsentrasi $1,22 \times 10^{8} \mathrm{spora} / \mathrm{ml}$. Gejala awal pada ulat yang telah memakan pakan yang diberi perlakuan adalah terjadinya perubahan perilaku ulat. Ulat yg terinfeksi bergerak menjauhi pakan atau kehilangan nafsu makan, sedangkan pada kontral ulat tetap memakan daun kubis. Gejala lain yang timbul adalah gerakan ulat menjadi lambat, kotoran (faces) agak cair atau diarhe, berbeda dengan faces kontrol yang tetap berupa butiarn-butiran. Ulat yg telah terinfeksi ini akhirnya akan mati, warna tubuh menjadi kehitam-hitaman dan tubuhnya lembek (Poinar and Thomas, 1982). Bila disentuh kulit ulat akan pecah dan mengeluarkan cairan berwarna hitam dan berbau busuk. timbulnya warna hitam menurut Steinhaus (1949) disebabkan karena bakteri tubuh sampai ke bagian haemokoel sehingga sel-sel darah menjadi keracunan.

Perubahan perilaku ini menyebabkan ulat menjadi gelisah dan terjadinya paralisis. Ulat yang mengalami paralisis ini menunjukkan bahwa kondisi ulat telah lemah atau sistem pertahanan ulat-ulat bekerja dengan baik sehingga spora yang berada dalam saluran pencernaan lebih mudah menyebabkan infeksi pada ulat.

\section{KESIMPULAN DAN SARAN}

\section{Kesimpulan}

Upaya pencaharian strain bakteri endogenik dari 3 kabupaten di Provinsi Sulawesi Utara dengan pendekatan isolasi selektif telah berhasil memperoleh sejumlah 411 isolat yang berdasarkan karakteristiknya diidentifikasi sebagai anggota $B$. thuringiensis 145 isolat, $B$. cereus 202 isolat dan $B$. sphaericus sebanyak 64 isolat.

Di antara 202 isolat $B$. cereus dipilih 15 isolat yang diuji daya bunuhnya terhadap larva $P$. xylostella dan terdapat 10 isolat yang dapat dianggap potensial karena mampu menimbulkan mortalitas $\geq 50 \%$ larva uji setelah waktu pendedahan 96 jam.

\section{Saran}

Dari pengalaman yang diperoleh selama penelitian ini dapat disarankan hal-hal berikut : 1) untuk mendapatkan gambaran yang lebih pasti mengenai keberadaan dan dinamika strain bakteri entomopatogenik di berbagai daerah sumber sampel perlu dilakukan penelitian yang bersifat longitudinal dengan cara pengambilan sampel secara periodik selama waktu tertentu. 2) agar potensi strain-strain bakteri unggul yang diperoleh dalam penelitian ini 
dapat diwujudkan menjadi biopestisida yang bermanfaat bagi pengendalian hama kubis secara ramah lingkungan, perlu dilakukan uji efikasi dan pilot project untuk produksi secara komersial.

\section{DAFTAR PUSAKA}

Agaisse, H. \& Lereclus, D. 1995. How does Bacillus thuringiensis produce so much insecticidal crystal protein? Journal of Bacteriology 17, 6027-6032.

Alexander, B. \& Priest, F.G. 1990. Numerical classification and identification of Bacillus thuringiensis including some strain pathogenic for mosquito larvae. Journal of General Microbioloy 136, 367-376.

Bravo, A. 1997. Phylogeneric relationship of Bacillus thuringiensis $\delta$-endotoxin family proteins and their functional domains. Journal of Bacteriology 179, 2793-2801.

Burges, H.D. and N.W. Hussey, 1971. Microbial Control of Insect And Mites. Academic Press, New York.

Binoto, P.D., 2001. Isolasi dan Uji Patogenisitas Bacillus cereus Frank. Serta Daya Bunuh Kombinasi dengan Sihalotrin Terhadap Crocidolomia binotalis Zell. (Lepidoptera; Pyraidae). Tesis. Program Pasca Sarjana. Universitas Gadjah Mada. Yogyakarta.

Capinera, J.L., 2000. Plutella xylostella. http://creatures.ifas.ufl.edu/leaf/diamondba ckpupa.html. Diakses 28 Juni 2011.Biological Control of Insect

Gordon, R.E, W.C. Haynes, and C.H. Pang, 1973. The Genus Bacillus Agriculture Researh Service. United Stated Departement of Agriculture.

Granum, P.E., Brymestad, S., O'Sullivan, K. \& Nissen, H. 1993. The enterotoxin from Bacillus cereus: production and biochemical characterization. Netherlands Milk and Diary Journal 47, 53-70.

Groschulski, P., Masson, L., Borisova, M. et.al. 1995. Bacillus thuringiensis CryllA(a) insecticidal toxin: crystal structure and channel formation. Journal of Molecular Biology 254, 447-464.
Hall, I.M. 1964. Use of Micro-organisms in Biological Control". In Biological Control of Insect Pest and Weeds. (Eds.) Paul DeBach. New York: Reinhold Pub.Corp.

Husaini, A. 2010. Manfaat Brokoli dan Kembang Kol. http://hidupsehat-dr-alamblogspot.com/2010/04/manfaat-brokolidan-kembang-kol.html.

Heimpel. A.M. and A.t. Angus. 1967. Disease Caused by Certain Sporeforming Bacteria. In E.A. Steinhaus (Eds) Insect Pathology and Advanced Trastise vol.2; Academic Press, New York.

Kimball, J.W. 1965. Biology, Addison.. Wesley Publishing Company. London.

Krych, V., Johnson, J.L. \&Youstern, A.A. 1980. Deoxyribonucleic acid homologies among strain of Bacillus sphaericus. International journal of Systematic Bacteriology 30, 476484.

Lencher, S., Mayr, R., Francis. K.P. et al. 1998. Bacillus weibenstephanensis sp. now. is a new psychorotolerant species of the Bacillus cereus group. International Journal of Systematic Bacteriology 48, 1373-1382.

Oka, I.N., 1995. Pengendalian Hama dan Implementasinya Di Indonesia. Gadjah Mada University Press.

Ohba, M and K. Aizawa. 1986. Distribution of Bacillus thuringiensis in Soil of Japan. Journal of Invertebrate Pathology.37:277282.

Parry, J.M., P.C.B. Turnbull dan J.R. Gibson. 1983. A Colour Atlas of Bacillus Species. Wolfe Medical Publication Ltd.

Poinar.G.O. and G.M. Thomas. 1982. Diagnostik Manual for the Identification of Insect Pathogen. Press. New York.

Rondonuwu, S., D. Tarore dan C. Salaki. 2003. Survey populasi dan Penyebaran Vektor demam Berdarah serta faktor-faktor penyebabnya. Fakultas Pertanian Universitas Sam Ratulangi Manado.

Rukmana, R. 1996. Kubis. Seri Budidaya. Penerbit Kanisius. Yogyakarta. 
Salaki, C. 2010. Keanekaragaman Genetik Isolat Bacillus thuringiensis Berliner Endogen Indonesia Sebagai Agensia Pengendali Hayati Hama Crocidolomia binotalis Zell. (Lepidoptera; Pyralidae) Pada Tanaman Kubis. Disertasi. Fakultas Biologi Universitas Gadjah Mada. Yogyakarta.

Salaki, C., Situmoran, J., Sembiring, L., dan Handayani, N.S. 2010. Isolasi dan karakterisasi bakteri indigeneous Indonesia (Bacillus thuringiensis) yang berpotensi sebagai agensia pengendali hayati serangga hama kubis (Crocidolomia binotalis). Jurnal IImu Pertanian AGRIVITA. 31(2): 174-181.

Steinhaus, E.A. 1949. Principle of Insect Pathology. Mc.Graw-Hill Publication in the Agriculture Science. First Edition. New York Toronto
London Mc. Graw Hill Book Company, INC.

Sembel, D.T. 2010. Pengendalian Hayati-Hamahama Serangga Tropis dan Gulma. Andi Offset. Yogyakarta.

Untung, K. 2006. Pengantar Pengeloalaan Hama Terpadu. Gadjah Mada University Press. Yogyakarta.

WHO. 1991. Biological Control VectorUNDP/World BankWHO, Special Programme for Research and Training in Tropical Diseases. Geneva.

Wikipedia, 2011. Brokoli, Manfaat dan kehebatannya bagi kesehatan manusia. http://mediaanakindonesia.wordpress.com/ 2011/05124/brokoli-manfaat-dankehebatannya-bagi-kesehatan-manusia/. 
